\title{
A kis értékü követelések európai eljárásának implementálása az Európai Unió egyes tagállamaiban
}

kis értékü követelés - európai polgári eljárásjog - bírósági eljárás - polgári per

\begin{abstract}
A tanulmány célja a 861/2007/EK rendelettel ${ }^{1}$ - a kis értékü követelések vonatkozásában - létrehozott, sui generis európai eljárás vizsgálata, melynek általános célkitűzései az igazságszolgáltatáshoz való hozzáférés javítása, az ítéletek kölcsönös elismerése és a belső piac jobb müködése, míg a specifikus céljai a kis értékü követelések érvényesítésének egyszerűsítése, ezen peres eljárások gyorsítása, és a költségek csökkentése, valamint az elismerés és végrehajtás terén a közbenső eljárások (exequatur) eltörlése. Ezen célokat részben sikerült megvalósítani, hiszen például az automatikus elismeréssel és a végrehajtási tanúsítvány kiállításával a végrehajtás kérelmezése egyszerübbé vált. ${ }^{2}$

A tanulmány megvizsgálja a rendelet alkalmazását az egyes tagállamokban, az ezzel kapcsolatban felmerült jogalkalmazási kérdéseket, illetve hogy mennyiben okozott nehézséget a tagállami jogszabályok összeegyeztetése a rendelettel. Kitér azokra a szabályozási területekre, ahol a rendelet a tagállami jogra támaszkodik, ezáltal a jogalkalmazóknak a gyakorlatban együtt kell a két szabályozási szintet alkalmazni, és feltárja, hogy ez miként valósult meg. Ehhez a rendelet hatálybalépése ${ }^{3}$ óta eltelt hét év adatai állnak rendelkezésre. Meg kell jegyezni, hogy 2015 decemberében fogadták el a rendelet módosítását, ami 2017. július 14-től alkalmazandó. Jelen tanulmánynak nem tárgya a módosítások elemzése, mivel a tagállami tapasztalatok egyelőre a jelenleg hatályos rendelet alapján vizsgálhatók.

A rendelet szerint a tagállamok tájékoztatják a Bizottságot a kis értékű követelések európai eljárásának (a továbbiakban: ESCeljárás) határokon átnyúló müködésével kapcsolatban. Az adatszolgáltatást a tagállamoknak még a rendelet felülvizsgálatát megelőzően ${ }^{4}$ kellett teljesíteniük. A tagállamok 2013 áprilisában kaptak egy
\end{abstract}

* Dr. Nyilas Anna egyetemi adjunktus, Debreceni Egyetem Állam- és Jogtudományi Kar Polgári Eljárásjogi Tanszék, nyilas.anna@law.unideb.hu.

1 Az Európai Parlament és a Tanács 861/2007/EK rendelete (2007. július 11.) a kis értékü követelések európai eljárásának bevezetéséröl, JO L 199 du 31.7.2007, 1-22.

2 NYILAs Anna: A polgári per egyszerüsítésének és gyorsításának eszközei az európai jogrendszerekben, különös tekintettel a kis értékű követelésekre vonatkozó eljárásokra. PhD-dolgozat, Debrecen, Debreceni Egyetem Marton Géza Állam- és Jogtudományi Doktori Iskola, 2011, 347.

3 A rendeletet 2009. január 1-jétöl kell alkalmazni.

4 A kötelező felülvizsgálat határideje 2014. január 1. volt. 
részletes kérdőívet a rendelet gyakorlati alkalmazásáról, melyre 2013. május 15-ig kellett válaszolniuk. Összesen 20 tagállam küldte el válaszát, Magyarország nem volt közöttük. ${ }^{5} \mathrm{Az}$ elkészült bizottsági jelentés megállapította, hogy általánosságban az eljárás megkönnyítette a kis értékü követelések határokon átnyúló érvényesítését. Ezen jogviták költsége akár 40\%-kal, időtartamuk pedig a megelőző 2 év 5 hónapról átlagosan 5 hónapra csökkent. Az európai eljárás olcsóbbnak bizonyult a tagállamok egyszerüsített eljárásainál. ${ }^{6} \mathrm{~A}$ tagállami válaszok azonban több kérdésben is igen eltérőek voltak, és felvetettek néhány gyakorlati jogalkalmazási kérdést, többek között azt, hogy a rendelet hatékony érvényesülése nem minden területen biztosított. ${ }^{7}$ Jelen tanulmányhoz reprezentatív jelleggel választottunk ki néhány tagállamot, melyek amellett, hogy jól mutatják a szabályozás sokszínűségét, lehetőséget kínáltak a tipizálásra és a közös nevezők meghatározására.

\section{A jogi szabályozás szintjei}

A kis értékű követelések európai eljárására elsődlegesen a 861/2007/EK rendelet irányadó. Amennyiben a rendelet egy kérdést nem szabályoz, vagy kifejezetten a tagállamok szabályozására hagy, abban az esetben lesz a tagállami eljárásjogi törvény alkalmazandó. A következőkben megvizsgáljuk a nemzeti jogalkotó részére hagyott „szabad mozgás” körébe tartozó területek egyes tagállamokban megvalósított technikáit. A rendelet e szabályozási területeket nem harmonizálta, ezért a tagállamok eltérően rendezik a rendelet alkalmazásával összefüggő kérdéseket. Mivel azonban a rendelet a tagállami jogszabállyal együttesen alkalmazandó, és több lényeges ponton a tagállami eljárásjogra támaszkodik, ténylegesen szükséges az ebből adódó nehézségeket feloldani, az esetleges jogösszeütközéseket kiküszöbölni, és a nem egyértelmú szabályokat értelmezni.

Egyes tagállamokban teljeskörüen, külön jogszabályban (például Hollandiában) ${ }^{8}$ vagy a polgári eljárási kódex külön fejezetében szabályozták a rendelet alkalmazásával összefüggő kérdéseket (utóbbiakra példa Németország, Franciaország, Anglia). ${ }^{9}$ Más tagállamok csak ad hoc módon szabályoztak egyes kérdéseket. Hazánkra

5 Ausztria, Bulgária, Ciprus, Csehország, Németország, Észtország, Görögország, Spanyolország, Finnország, Franciaország, Olaszország, Litvánia, Málta, Hollandia, Lengyelország, Portugália, Svédország, Szlovénia, Szlovákia és az Egyesült Királyság.

6 A Bizottság jelentése a Tanácsnak, az Európai Parlamentnek és az Európai Gazdasági és Szociális Bizottságnak a kis értékű követelések európai eljárásának bevezetéséről szóló 861/2007/EK európai parlamenti és tanácsi rendelet alkalmazásáról, Brüsszel, 2013. 11. 19., COM(2013) 795 final. http://eur-lex.europa.eu/ legal-content/HU/TXT/HTML/?uri=CELEX:52013DC0795\&from=EN (2016. 06. 20.).

7 A probléma nem csak az ESC-rendelet esetében áll fenn, lásd pl. HARSÁGı Viktória: Az európai fizetési meghagyásos eljárásról szóló rendelet más közösségi jogforrások és a tagállami szabályozások feszültségi mezőjében. Közjegyzők Közlönye, 2012/6, 4-26.

8 Uitvoeringswet verordening Europese procedure voor geringe vorderingen. https://www.eerstekamer. nl/9370000/1/j9vvhwtbnzpbzzc/vi6pbevy24w7/f=y.pdf (2016. 10. 27.).

9 Németország: § 1097-1109 Zivilprozessordnung (ZPO); Franciaország: Articles 1382-1392 Code de procedure civile (CPC); Anglia és Wales: Part 78.12-78.22 of the Civil Procedure Rules (CPR), Practice Direction 78 . 
is ez a megoldás jellemző. ${ }^{10}$ Nyilvánvaló, hogy ez az esetleges és töredezett szabályozás nem szolgálja a jogkeresők tájékoztatását és az eljárási szabályok könnyebb alkalmazhatóságát. ${ }^{11}$

\subsection{Külön törvényi szabályozás}

Hollandiában külön törvénnyel, a 2009. május 29-i 31 596. számú törvénnyel szabályozták a rendelet alkalmazásával összefüggő kérdéseket. ${ }^{12} \mathrm{~A}$ holland törvény tartalmazza az európai kis értékü követelés rendelet szerinti definícióját, és kimondja, hogy ezen jogviták kantonbírósági útra tartoznak. Végül rögzíti, hogy a Hollandiában benyújtott ESC-keresetlevelekre a kérelemre történő eljárás (verzoekschriftprocedure) szabályai irányadók (9. cikk). ${ }^{13}$ Finnországban a 753/2008. törvény tartalmazza a rendelet alkalmazásával összefüggő kérdéseket. Svédországban szintén külön jogszabály, az SFS 2008.1038. számú törvény, hét szakaszban szabályozza az ESCeljárást. A kérelmek vizsgálata a kerületi bíróságok (tingsrätt) hatáskörébe tartozik.

\subsection{Elhelyezés a tagállami polgári eljárásjogi törvényben}

Franciaországban a 2008-1346. számú, 2008. december 17-i törvény módosította a polgári eljárásjogi kódexet, egy új fejezet beépítésével a III. Könyv, IV. Cím, 1. fejezet alá. Az 1382-1390. cikk tárgyalja az ESC-eljárást. Az eljárásra a kerületi bíróságok (tribunal d'instance) és a kereskedelmi bíróságok (tribunal de commerce) rendelkeznek hatáskörrel. Anglia és Wales az eljárást a CPR. 78. fejezetében szabályozta, a 78.12. szakasztól. A fejezet fogalommeghatározásokkal kezdődik, a 78.14. szerint a kereseti kérelmeket a small claims track szabályai szerint kell elbírálni (27. Rész). Luxemburgban a 2009. március 13-i törvény iktatta be az új polgári eljárásjogi kódex 143-1 cikkét, a kis értékü követelések európai eljárásáról. Eszerint a békebírók hatáskörébe tartozik az eljárás. Lengyelországban a polgári eljárásjogi

10 Ennek egyik példája a Pp. 314. § szakasz (3) bekezdése, mely az egymillió forintot meg nem haladó pénzkövetelések ilyen módon történő érvényesíthetőségét mondja ki, ezáltal a fizetési meghagyásos eljárás egyik lehetséges alternatívájaként kezeli a vizsgált európai eljárást. Lásd ehhez MoLnÁR Judit: Alternatívák most és a jövőben is? Az egymillió forintot meg nem haladó pénzkövetelések érvényesítése Magyarországon. Jog Állam Politika, 2016/2, 157-158.

11 Az új polgári perrendtartásról szóló 2016. évi CXXX. törvény külön fejezetben szabályozza a külföldi eljárásokkal kapcsolatos kérdéseket, a XLV. Fejezet tartalmazza a külföldi elem esetén alkalmazandó különleges rendelkezéseket. Ezen belül találjuk a kis értékü követelések európai eljárására vonatkozó rendelkezéseket. Véleményünk szerint az új Pp.-ben szerkezetileg megfelelő a rendelet alkalmazásával összefüggő szabályok elhelyezése. E megjelenítés segíti az eljárás fellelhetőségét, ezáltal a jogalkalmazók munkáját, illetve az eljárás megismerését a jogkeresők számára.

12 Wet van 29 mei 2009 tot uitvoering van verordening (EG) nr. 861/2007 van het Europees Parlement en de Raad van de Europese Unie van 11 juli 2007 tot vaststelling van een Europese procedure voor geringe vorderingen (OJEU L 199). http://wetten.overheid.nl/BWBR0025914/2010-11-01 (2016. 11. 10.).

$13 \mathrm{http}: / /$ collegebundel.nl/uitvoeringswet-verordening-europese-procedure-voor-geringe-vorderingen (2016. 06. 20.). 
kódex 7. része tartalmazza a határon átnyúló európai eljárások szabályait. A 2. fejezet tárgyalja az ESC-eljárást, a 505. 21. §-tól az 505. 27a. §-ig. A fejezet szabályait nem lehet együtt alkalmazni más különleges eljárási szabályokkal. A német ZPOban külön fejezet ${ }^{14}$ szabályozza a rendelet alkalmazásával összefüggő kérdéseket. A hatáskört és illetékességet külön nem szabályozzák, arra a ZPO általános szabályai alkalmazandóak. Ausztriában szintén a polgári eljárásjogi törvénybe (öZPO), az 548. § szakaszba került be az ESC-eljárás. A 2007. július 24-én hatályba lépett bolgár polgári eljárásjogi törvény 7 . része szabályozza a közösségi jog müködésével összefüggő eljárási szabályokat. ${ }^{15} \mathrm{Nem}$ találjuk azonban külön fejezetben az ESCeljárás szabályait, hanem csak utalásszerüen, és csak egyetlen helyen, a végrehajtás elrendelése iránti kérelemnél, amely a 624. szakasz szerint az adós állandó lakóhelye vagy székhelye, vagy a teljesítés helye szerinti körzeti bíróságon nyújtható be. Így Bulgáriában nem jelenik meg az eljárásjogi törvényben az ESC-eljárás, a hatályos magyar szabályozáshoz hasonlóan, hanem ténylegesen közvetlenül a rendeletet alkalmazzák, illetve a tagállami eljárási jogot.

\section{A tagállami jogszabályok által érintett kérdéskörök}

A szabályozások áttekintése alapján megállapíthatjuk, hogy a legtöbb tagállamban szerepelt a vonatkozó jogszabályban a végrehajtási tanúsítványt kiállító hatóság és a tanúsítvány elfogadott nyelve; a végrehajtás felfüggesztésére és korlátozására jogosult hatóság; az ESC-eljárásban hatáskörrel és illetékességgel rendelkező bíróság; az eljárási szabályok arra az esetre, ha a kereset vagy a viszontkereset a rendelet hatályán kívül eső ügyre vonatkozik; és a fellebbezés megengedhetősége. $E$ pontok részben egybeesnek a Bizottság részére nyújtott tájékoztatás kérdésköreivel, ezért azok részletes elemzését lásd a 3. pontban. A következőkben tehát csak a tájékoztatás körén kívül eső szabályozási tárgykörökre térünk ki.

\subsection{A kereset/viszontkereset nem tartozik a rendelet hatálya alá}

A vizsgált tagállamok mindegyike rendelkezett arról, hogy mely eljárási szabályok szerint folytatják az eljárást, ha a rendelet nem alkalmazható, és a fél nem vonja vissza a keresetet vagy viszontkeresetet. Emellett voltak olyan tagállamok, melyek törvényi határidőket írtak elő a bíróság döntésére, és a fél keresetlevél, illetve viszontkereset visszavonásának közlésére. Egyes tagállamok a közlés módját is meghatározták. Végül, ahol a bíróság hatáskörére vonatkozóan speciális szabályok érvényesültek az ESC-eljárásban, rendelkezni kellett a hatáskör vizsgálatáról és az

14 Abschnitt 6. Europäisches Verfahren für geringfügige Forderungen nach der Verordnung (EG) Nr. 861/2007. https://www.gesetze-im-internet.de/zpo/BJNR005330950.html\#BJNR005330950BJNG080000160 (2016. 06. 20.).

15 Consumers' cross-border disputes resolution: European Order of Payment and European Small Claims Procedure, Lithuanian Consumer Institute, Vilnius, 2011., 29. http://www.vartotojai.It/get.php?f.1753. (2016. 06. 20.). 
áttétel lehetőségéről, amennyiben nem a rendelet szerint kell folytatni az eljárást. Külön rendelkezést tartalmaz e kérdés esetén a finn ${ }^{16}$ és a francia eljárási szabályozás. ${ }^{17}$

A holland törvény 4. cikke rendelkezik a kereset visszavonásáról. Amennyiben a felperes vagy az alperes nem vonja vissza a keresetet, illetve viszontkeresetet, a Polgári eljárásjogi törvénykönyv 69 . szakasza alkalmazandó. ${ }^{18} \mathrm{~A} 4$. cikk szerint a kereset vagy viszontkereset visszavonását a tájékoztatás kézhezvételétől számított 30 napon belül kell írásban közölni a bírósággal.

A finn törvény 3 . szakasza rendelkezik a polgári peres eljárásra való áttérésröl, amennyiben a követelés nem tartozik a rendelet hatálya alá. Ha a keresetet vagy a viszontkeresetet nem a rendelet szabályai szerint bírálják el, a Körzeti Bíróság tájékoztatja a felperest és az alperest, hogy az ügy tárgyalása a Bírósági Eljárási Kódex 5. fejezet 15. szakasza szerint folytatódik. Ezalatt a sommás eljárást kell érteni. ${ }^{19}$ Ezzel egyidejüleg a bíróság tájékoztatja a feleket, hogy az előkészítés írásban vagy szóban fog folytatódni, tárgyalás keretében, vagy egyből az érdemi szakasz következik. Amennyiben az alperes írásban érdemi (a jogalapot és a bizonyítékokat is tartalmazó) védekezést terjeszt elő a megadott határidőn belül, a rendes peres eljárás szabályai szerint folytatják a tárgyalást.

A francia CPC 1384. szakasza szerint, ha az tünik ki a keresetlevélböl, hogy nem tartozik a rendelet hatálya alá az ügy, a bíróság ezt ajánlott tértivevényes levélben közli a felperessel. Ebben kitúz egy határidőt a kereset visszavonására, azzal a felhívással, hogy amennyiben a felperes azt nem vonja vissza, a bíróság a rá (a tribunal d'instance bíróságra) irányadó eljárási szabályok szerint fogja az eljárást lefolytatni. Ha a felperes nem vonta vissza a keresetét, a bíróság megállapítja, hogy nem alkalmazható az ESC-eljárás, és felhívja a felperest, hogy idézze meg az alperest „signification” útján. Erről a bíróság végzést hoz, melyet szintén ajánlott tértivevényes levélben kézbesít a felperes részére. Az előbbiekhez hasonlóan rendelkezik a viszontkeresetről is.

Az angol CPR 78.15. szakasza szerint, ha a bíróság határidőben nem kap a felperestöl a visszavonásról szóló értesítést, a kereseti kérelmet úgy kell tekinteni, mintha a 7. Rész szerint nyújtották volna be (az általános perszabályok), és e rész szabályait kell alkalmazni az eljárás megindítására. Ha a bíróság megállapítja, hogy a követelés a rendelet hatályán kívül esik, tájékoztatja a felperest egy „Tájékoztatás az áttérésről" értesítés küldésével. Ha a felperes vissza kívánja vonni a keresetét, erről a bíróságot az értesítés kézhezvételétől számított 21 napon belül kell tájékoztatnia. A 78.17. szakasz kiegészíti a rendelet 5. cikk (5) bekezdését a következőképpen: Az alperes válaszának a felperes részére történő megküldésével egyidejüleg a bíróság tájékoztatja a felperest, hogy a bíróság vizsgálja, hogy a követelés a rendelet hatálya alá tartozik-e, egy „Áttérés vizsgálatáról szóló” értesítésben, és ennek másolatát az alperes részére is megküldi. Ha a felperes visszavonja a kereseti kérelmét arra

\footnotetext{
16 753/2008. törvény 3. szakasz.

17 Code de procédure civile, Article 1384.

18 A keresetlevél nem megfelelő módon történő benyújtása esetére előírt helyesbítés és kiegészítés.

19 NIEMI, Johanna: Civil procedure in Finland. Kluwer Law International, The Netherlands, 2010, 123.
} 
az esetre, ha a bíróság megállapítja, hogy a követelés a rendelet hatályán kívül esik, a felperes köteles erröl értesíteni a bíróságot és az alperest, 21 napon belül, az „Áttérés vizsgálatáról szóló" értesítés kézhezvételétől. A bíróság értesíti az alperest és a felperest a döntéséröl, hogy a kereseti követelés a rendelet hatálya alá tartozik-e. A rendelet erre a döntésre 30 napos határidőt ír elö, az alperes válaszának a felperes részére történő megküldésétöl. Sajátos, hogy a felperesnek hamarabb kell eldöntenie, hogy vissza kívánja-e vonni a kereseti kérelmét, mint ahogy értesülne a bíróság döntéséröl a rendelet alkalmazhatósága kérdésében. Amennyiben az ESC szerinti viszontkereset meghaladja a 2. cikk (1) bekezdésében foglalt összeghatárt, a 78.18. szakasz irányadó, ugyanaz az eljárás, mint a kereset esetében.

A német ZPO szerint, amennyiben a kereset a rendelet hatályán kívül esö ügyre vonatkozik, a rendelet 4 . cikk (3) bekezdése értelmében a bíróság a rendelet alkalmazása nélkül folytatja az eljárást.

\subsection{A rendelet szerinti felülvizsgálat}

E kérdéskörben a tagállamok többsége ${ }^{20}$ szabályozta, hogy melyik bíróságnál kell kérelmezni a felülvizsgálatot. Egyes tagállamok elöírták a benyújtás határidejét, és a kérelem egyes kötelező tartalmi elemeit. Sajátos a lengyel szabályozás, amely külön fellebbezést enged a megsemmisítéssel szemben, ${ }^{21}$ a német és az osztrák törvény pedig részletezi a semmisség eljárás következményeit is. ${ }^{22}$

A holland törvény (6. cikk) rendelkezik arról, hogy a felülvizsgálatot az ítéletet hozó bíróságtól lehet kérelmezni, és mivel a rendelet nem tartalmazta ennek határidejét, így a törvény azt 4 hétben határozta meg az ítélet kézhezvételétöl, illetve az akadályozó körülmény megszünésétöl.

Az angol CPR 78. fejezete a felülvizsgálatra a 23. Rész szabályait rendeli alkalmazni, ami a bírósági végzés meghozatala iránti kérelem általános szabályait tartalmazza. A kérelmet indokolni kell, és meg kell jelölni, hogy konkrétan milyen döntést kérnek a bíróságtól. A lengyel törvény 505 . 27a. § szakasza alapján az ítéletet az azt meghozó bíróság semmisíti meg, az alperes kérelmére. A kérelemnek tartalmaznia kell az ítélet megsemmisítését megalapozó körülményeket. A kérelmet a bíróság tárgyaláson kívül bírálja el, elötte meghallgatja a felperest, vagy írásbeli nyilatkozattételre hívja fel. Az ítélet megsemmisítéséről szóló bírósági határozat fellebbezhető.

A német ZPO 1104. §-a rendelkezik arról, hogy ha az alperes önhibáján kívül mulasztott, a rendelet 18. cikke szerinti feltételekkel kérelmezheti a felülvizsgálatot, melyeket a kérelmezőnek kell valószínűsítenie. Ha a kérelem alapos, az eljárást folytatni kell, az ítélet meghozatala előtti időponttól. Kérelemre a bíróság megállapítja a korábban meghozott ítélet semmisségét.

20 Hollandia, Lengyelország, Németország, Ausztria, Anglia és Wales.

21 The European Small Claims procedure in Poland. http://www.europe-eje.eu/sites/default/files/pj/dossiers/ english_pol_petit_litigeenglish.pdf, 13. (2016.06. 20.).

22 ZPO 1104. §, ÖZPO 548. §. 
Az öZPO szintén tartalmazza, hogy a rendelet szerinti felülvizsgálatot az a bíróság folytatja le, amelyik első fokon eljárt az ESC-eljárásban. Ha a bíróság semmisnek nyilvánítja az ESC-ítéletet, a semmisségre okot adó cselekményt megelőző időpontba kell az eljárást visszahelyezni. ${ }^{23}$

\subsection{Elutasítás formai okok miatt}

Két tagállami jogszabály tartalmaz kifejezett elutasítási okot arra az esetre, ha a rendelet 4. cikk (4) bekezdése áll fenn. A CPC 1385. szakasza szerint, a francia bíróság a keresetet elutasítja, ha az nyilvánvalóan alaptalan, vagy nem bírálható el, vagy a felperes nem egészítette ki vagy javította ki a formanyomtatványt a megadott határidőn belül. Az elutasító döntés ellen nincs helye fellebbezésnek. A lengyel törvény is szabályozza ezt olyan módon, hogy ha a keresetlevelet a bíróság visszaküldi a fenti hiányosságok miatt a felperesnek, erröl külön végzést kell hoznia (505. 24. §). A végzés ellen fellebbezésnek van helye. ${ }^{24}$

\subsection{Tárgyalás}

Néhány tagállami jogszabály ${ }^{25}$ tartalmaz speciális rendelkezéseket a tárgyalásra. A francia CPC 1388. §-a értelmében, amennyiben az ESC-eljárásban tárgyalás tartására kerül sor, a bíróság a rá irányadó eljárási szabályok szerint folytatja azt le. A lengyel törvény ${ }^{26}$ kiemeli, hogy az ügy eldöntése tárgyaláson kívül történik. A bíróság tárgyalást tűzhet ki a rendelet által felsorolt esetekben. ${ }^{27} \mathrm{~A}$ tanú írásban tehet vallomást, ha a bíróság elrendeli, erre a bíróság által szabott határidőn belül van lehetősége. Az ítéletet a bíróság hivatalból kézbesíti a feleknek, a fellebbezésre vonatkozó tájékoztatással együtt.

A német szabályozásban (ZPO 1100. §) lehetőség van a távoli kommunikáció alkalmazására, azaz a fél és képviselője a bíróságtól eltérő helyen tartózkodhatnak, és ott eljárási cselekményeket végezhetnek, ha a bíróság ezt engedélyezi. A ZPO 275. § szerinti előrehozott tárgyalási nap alkalmazása azonban kizárt. A bizonyítás kapcsán az 1101. § kiemeli, hogy a bíróság elrendelheti a megfelelőnek tartott bizonyítást, ha a rendelet 9 . cikk (2) és (3) bekezdése nem zárja ki. A bíró elrendelheti a tanú, szakértő vagy fél távolsági meghallgatását.

A rendelet tartalmaz néhány speciális előírást a bizonyítással kapcsolatban, ezekre célszerü a tagállami perrendben egy utaló szabállyal felhívni a figyelmet. ${ }^{28} \mathrm{~A}$ sze-

23 ÖZPO 149. § és 153. § szakasz.

24 The European Small Claims procedure in Luxembourg. http://www.europe-eje.eu/sites/default/files/pj/ dossiers/lux_petit_litigeenglish.pdf (2016. 06. 20.).

25 Franciaország, Németország, Lengyelország.

26 Polgári eljárási törvény 505.23. szakasz. http://prawo.legeo.pl/prawo/kodeks-postepowania-cywilnego-zdnia-17-listopada-1964-r/czesc-pierwsza_ksiega-pierwsza_proces/?on=17.04.2016 (2016. 06. 20.).

27 Itt azonban nem jelöli meg a rendelet konkrét cikkeit.

28 861/2007/EK rendelet 9. cikk. 
mélyes jelenlét okozza az eljárási költségek egy jelentős részét. Az elektronikus technológiák azonban a legtöbb bíróságon nem elérhetők, hiába teszi lehetővé a rendelet annak alkalmazását. A felek költségeit pedig lényegesen csökkenti, ezért hosszú távon érdemes kiterjeszteni ezen lehetőséget. A videokonferencia útján tartott tárgyalás 10 tagállamban elérhető (Ausztria, Ciprus, Észtország, Finnország, Luxemburg, Málta, Hollandia, Portugália, Svédország, Egyesült Királyság). Magyarország 0\%-os adatot adott meg. Vannak olyan országok, ahol csak egyes bíróságokon érhető el, például Csehország, Franciaország, Németország, Írország, Olaszország, Lengyelország, Spanyolország. ${ }^{29}$

A hagyományos tárgyalás költsége 400-800 euró a fél számára, míg a távoli kommunikációval ez 100 euró, ami jelentős költségcsökkentést, ezenfelül 9 óra utazási idő megtakarítást jelent. A gyakorlatban igen korlátozottan valósult meg a távoli kommunikáció útján tartott tárgyalás. Egyes esetekben nem tájékoztatták a feleket ennek lehetőségéről, máskor a fél ez irányú kérelmét elutasították. ${ }^{30}$

\subsection{Mulasztási ítélet}

Azon tagállamokban, ahol a polgári peres eljárás ismeri a mulasztási ítéletet, külön kimondják, hogy a rendelet 7 . cikk (3) bekezdésének ${ }^{31}$ jogkövetkezménye mulasztási ítélet lesz. ${ }^{32}$ Ennek az alperes jogvédelme tekintetében lehet jelentősége, a jogorvoslat és a végrehajthatóság körében. Így a svéd jogalkotó fontosnak tartotta ezt szabályozni, valamint, hogy a mulasztási ítéletet mindkét fél részére kézbesíteni kell. A mulasztási ítélet elleni jogorvoslatot a kerületi bírósághoz kell benyújtani, a közlést követő 1 hónapon belül. ${ }^{33}$

A lengyel törvény (339. $§$ ) is kiemeli, hogy a rendelet 7 . cikk (3) bekezdése esetén a bíróság mulasztási ítéletet hoz. Az alperes ellene az általános szabályok szerint élhet fellebbezéssel.

A német ZPO 1103. § szakasza a mulasztás következményeit tartalmazza. Eszerint, ha a fél nem tesz meg egy nyilatkozatot határidőben, vagy nem jelenik meg a tárgyaláson, a bíróság a rendelkezésre álló iratok alapján hozhatja meg az ítéletet.

Az öZPO szerint, a rendelet 7. cikk (3) bekezdése alapján a bíróság hozhat mulasztási ítéletet a 396. § alkalmazásával. Ha a védekezés előterjesztése után, még az érdemi tárgyalás megkezdése előtt bármelyik fél elmulasztja a tárgyalást, a megjelent fél kérelmére mulasztási ítélet hozható. A 397.a § szakasz szerint ellentmondásnak van helye.

29 European Commission for the Efficiency of Justice, European Judicial Systems, Edition 2012 (2010 data), Efficiency and Quality of Justice, 115. http://www.coe.int/t/dghl/cooperation/cepej/evaluation/2012/Rapport_ en.pdf (2016. 06. 20.).

30 Assessment of the socio-economic impacts of the policy options for the future of the European Small Claims Regulation, Deloitte, 2013, 50. http://ec.europa.eu/justice/civil/files/small_claims_report_ia_en.pdf (2016. 06. 20.)

31 Amennyiben a bíróság az 5. cikk (3) vagy (6) bekezdésében foglalt határidőn belül nem kapja meg az érintett fél válasz-formanyomtatványát, a keresettel vagy a viszontkeresettel kapcsolatban ítéletet hoz.

32 Svédország, Lengyelország, Németország, Ausztria.

33 Lag (2008:1038) om europeiskt småmålsförfarande, 4. §. 


\subsection{Egyedi szabályozási kérdések}

Az angol CPR 78.13. szakasza foglalkozik a keresetlevél benyújtásával. Mivel a rendelet nem tartalmazza a hamis tényállitások következményeit, ezért a szabályokat kiegészítették azzal, hogy ha szándékosan hamis tényállítást tartalmaz a keresetlevél-formanyomtatvány, ugyanazon következményeket kell alkalmazni, a 32.14. szakasz szerint, mintha valódisági nyilatkozattal (statement of truth) lett volna ellátva a formanyomtatvány. Ugyanez vonatkozik az alperes válaszára is.

A ZPO 1098. § szakasza pedig rendelkezik a megtagadásról, amennyiben az irat nem a címzett által értett nyelven van [a rendelet 6 . cikk (3) bekezdése]. A megtagadás határideje egy hét, ez törvényi határidő, és az irat kézhezvételétől kezdődik. A címzettet tájékoztatni kell a határidő elmulasztásának következményeiről.

\section{A Bizottság felé fennálló információs kötelezettség területei}

A rendelet 25. cikke konkrét határidőt tartalmazott (2008. január 1.) a tagállami információk Bizottság részére történő megküldésére. A 25. cikk szerinti tájékoztatás a következökre terjed ki:

a) mely bíróságok rendelkeznek hatáskörrel és illetékességgel a kis értékủ követelések európai eljárásában ítélethozatalra;

b) a kis értékü követelések európai eljárásának céljaira elfogadott, és a bíróságok rendelkezésére álló kommunikációs eszközök, a 4. cikk (1) bekezdésével összhangban;

c) a 17. cikkel összhangban eljárási joguk értelmében, lehetőség van-e jogorvoslatra, és azt mely bírósághoz kell benyújtani;

d) a 21. cikk (2) bekezdésének $b$ ) pontja értelmében elfogadott nyelvek; valamint

e) mely hatóságoknak van hatásköre a végrehajtásra, és mely hatóságoknak van hatásköre a végrehajtás felfüggesztésére vagy korlátozására.

A Bizottság a kapott információkat a Polgári Ügyek Európai Igazságügyi Atlaszában $^{34}$ tette közzé. Ezeket áttekintve elég nagy az eltérés az információk részletességét és pontosságát illetően. ${ }^{35}$ Mégis, a szolgáltatott adatok alapján képet kaphatunk a tagállami eljárási szabályok közötti föbb eltérésekröl, ami kihatással van a rendelet alkalmazására.

\subsection{A tagállamban hatáskörrel és illetékességgel rendelkező bíróság}

A tagállamok többsége az eljárásra hatáskörrel és illetékességgel rendelkező bíróságként a hazai kis értékű követelésekre is hatáskörrel rendelkező általános első-

34 http://ec.europa.eu/justice_home/judicialatlascivil/html/index_hu.htm (2016. 06. 20.).

35 Das Europäische Bagatellverfahren und das Europäische Mahnverfahren: Theoretisch einfach - praktisch kompliziert, 3. http://www.europe-consommateurs.eu/fileadmin/user_upload/eu verbraucher/PDF_Englisch/ Studie_ZEV_Vereinfachte_Verfahren.pdf (2016. 06. 20.). 
fokú bíróságot jelölte meg. Nem minden tagállamban létezik azonban külön hazai eljárás a kis értékü követelésekre (ez a helyzet Ausztriában, Bulgáriában, Csehországban, Finnországban, Magyarországon pedig csak fizetési meghagyásos eljárást követően indítható). Az illetékességre az általános szabályok irányadók a tagállamokban.

Egyes tagállamok egy vagy több bíróságot jelöltek ki a kis értékű követelések európai eljárásának lefolytatására (például Finnország, Málta, valamint a németországi Hessen tartomány). Málta különbíróságot hozott létre a kis értékü követelésekre. Finnország, ahol egyébként nincs kis értékű követelések bírósága, azt a megoldást választotta, hogy a Helsinki Körzeti Bíróság rendelkezik hatáskörrel. ${ }^{36}$ Az ilyen koncentráció bizonyos előnyökkel jár, mint például a bírósági szakismeret és a nyelvi készségek koncentrálódása, valamint egyszerübb a költségmegtakarítást lehetővé tévő távolsági kapcsolattartási eszközök kiépítése, ha azokat egy vagy csak néhány bíróságon kell telepíteni. ${ }^{37}$

\subsection{Kapcsolattartási módok a felek és a bíróság között}

A rendelet három esetben írja elő a szigorúbb, a címzett általi átvétel bizonyítékával történő kézbesítést, a keresetlevél-formanyomtatvány bírósághoz történő benyújtására, ${ }^{38}$ az alperes jogaira nézve garanciális jelentőségű iratokra, azaz a keresetről való tájékoztatásra ${ }^{39}$ és a bírósági ítéletre. ${ }^{40} \mathrm{~A}$ többi esetben egyszerübb formák is alkalmazhatók, így az idézésre, a hiánypótlásra, a további információ kérésére. ${ }^{41}$

A keresetlevél tekintetében a legtöbb tagállam ajánlott postai levelet fogad el, vagy esetenként közvetlen benyújtást a bíróságra. Néhány tagállam a faxot, és egyes bíróságok vonatkozásában elektronikus benyújtást. ${ }^{42}$ A ZPO 1097 . §-a kimondja, hogy a rendelet szerinti formanyomtatványok, egyéb kérelmek és nyilatkozatok a 130.a szakasz szerint elektronikus úton is benyújthatók, írásbeli beadványként vagy faxon. Ausztriában a keresetlevelet papíralapon vagy elektronikusan lehet benyújtani az ERV (Elektronischer Rechtsverkehr) rendszeren ${ }^{43}$ keresztül. Kifejezetten kizárt a faxon vagy e-mailben történő benyújtás. ${ }^{44}$ Finnországban a rendelet 4 . cikkének

36 https://e-justice.europa.eu/content_small_claims-42-fi-en.do?member=1 (2016. 06. 20.).

37 Ezen módszer hatékonyságáról lásd pl. ÁLBERS, Pim: Reducing delays: recent developments in the Netherlands. In: Practical ways of combating delays in the justice system, excessive workloads of judges and case backlogs, CEPEJ(2005) 7, Strasbourg, 2005, 9.

38 4. cikk.

39 5. cikk (2) bekezdés.

40 7. cikk (2) bekezdés.

41 A 13. cikk szerint.

42 Csehország, Észtország, Ciprus, Ausztria, Portugália, Szlovénia, Szlovákia. Az Egyesült Királyságban postai úton kell benyújtani a keresetlevelet, de a csatolt mellékletek e-mailben is beküldhetők.

43 Elektronikus benyújtási és kézbesítési rendszer. Az ERV olyan elektronikus kommunikáció a felek és a bíróság között, mely egyenértékű a papíralapú kommunikációval, és lehetővé teszi az adatok strukturált, biztonságos, papírmentes továbbítását a felek és a bíróság között, mindkét irányban.

44 MAYr, Peter G.: Das Europäische Bagatellverfahren in Österreich. Zeitschrift für Verkehrsrecht, 2009/19, 40-45. 
(1) bekezdésében említett keresetlevél közvetlenül megküldhető a Helsinki Kerületi Bíróság Hivatala számára - az elektronikus szolgáltatásokról és távközlésröl szóló törvény elöírásainak megfelelöen - postai úton, faxon, illetve e-mailben. ${ }^{45}$ A svéd törvény szerint az ESC iránti kérelmeket közvetlenül (személyesen) vagy postai úton kell benyújtani az illetékes bírósághoz ${ }^{46} \mathrm{~A}$ lengye ${ }^{47}$ és a bolgár bíróság a formanyomtatványokat közvetlen benyújtás útján vagy postai úton fogadja el..$^{48} \mathrm{Lu}$ xemburg kommunikációs eszközként a postai kézbesítést fogadja el ${ }^{49} \mathrm{~A}$ luxemburgi törvény szerint a keresetlevél és a válasz-formanyomtatvány kézbesítése ajánlott tértivevényes levélben történik, ha az alperes Luxemburgban rendelkezik lakóhelylyel. ${ }^{50}$ Ha másik tagállamban lakik az alperes, az 1393/2007/EK rendelet szerinti átvevő intézmények részére történik a kézbesítés. Azonban a luxemburgi törvény szerint az ítélet kézbesítésének két módja lehetséges. Ha bírósági végrehajtó által történik, akkor nem automatikus, azt a jogosultnak kell kérelmeznie, egy bírósági végrehajtótól. A másik kézbesítési forma a „notification”, ami a bírósági hivatalnok feladata (greffe). A két kézbesítési mód közül az eljáró bíróság választ. ${ }^{51}$

Tíz tagállam (Ausztria, Észtország, Ciprus, Csehország - bár itt e-mailben vagy faxon történő benyújtás esetén később az eredeti példányt is be kell nyújtani -, Finnország, Franciaország, Hollandia - itt azonban a gyakorlatban nem használják ${ }^{52}$-, Portugália, Szlovénia, Anglia és Wales) és öt német tartomány (Berlin, Brandenburg, Bréma, Szászország, Hessen) határokon átnyúló ügyekben lehetővé teszi a keresetek elektronikus úton történő benyújtását. Az ilyen irányú fejlődés valószínüleg még hangsúlyosabbá válik a jövőben, mivel az európai e-igazságügyi kommunikáció (e-Codex) elnevezésű kísérleti projekt keretében vizsgálják annak megvalósíthatóságát, hogy egy központosított európai elektronikus keresetbenyújtási rendszert hozzanak létre az ESC-eljárás számára. Az e-Codex segítségével az eljárás online elérhető lesz, az Európai Igazságügyi Portál vagy a nemzeti honlapokon keresztül. ${ }^{53}$

45 Information communicated by Member States in accordance with Article 25 of Regulation (EC) No 861/2007 of the European Parliament and the Council of 11 July 2007 establishing a European Small Claims Procedure. http://ec.europa.eu/justice_home/judicialatlascivil/html/pdf/vers_consolide_en_861.pdf (2016. 06. 20.), 44.

46 SFS 2008.1038. számú törvény. https://www.riksdagen.se/sv/dokument-lagar/dokument/svensk-forfattningssamling/lag-20081038-om-europeiskt-smamalsforfarande_sfs-2008-1038 (2016. 06. 20.).

47 Kodeks postępowania cywilnego, 125. § 1 és 2 cikke, 126. § 1 és 2 cikke, és 187 . 11 cikke alkalmazandó.

48 Information communicated by Member States in accordance with Article 25 of Regulation (EC) No 861/2007 of the European Parliament and the Council of 11 July 2007 establishing a European Small Claims Procedure. http://ec.europa.eu/justice_home/judicialatlascivil/html/pdf/vers_consolide_en_861.pdf (2016. 06. 20.), 4.

49 Information communicated by Member States in accordance with Article 25 of Regulation (EC) No 861/2007 of the European Parliament and the Council of 11 July 2007 establishing a European Small Claims Procedure. http://ec.europa.eu/justice_home/judicialatlascivil/html/pdf/vers_consolide_en_861.pdf (2016. 06. 20.), 26.

50 The European Small Claims procedure in Luxembourg. http://www.europe-eje.eu/sites/default/files/pj/ dossiers/lux_petit_litigeenglish.pdf (2016. 06. 20.), 8.

51 https://e-justice.europa.eu/content_small_claims-354-lu-hu.do?member=1 (2016. 06. 20.).

52 KRAMER, Xandra E.: Small claim, simple recovery? The European small claims procedure and its implementation in the member states. ERA Forum, 2011/1, 119-133.

53 http://www.e-codex.eu/pilots/small-claims.html (2016. 06. 20.). 
Néhány tagállamban gondot okozott a kézbesítés, mivel nem mindenhol megszokott, hogy ez a bíróság feladata. ${ }^{54}$ Emellett az alperes hatályos kézbesítési címének meghatározása nehézségekbe ütközött, számos alkalommal nem érkezett vissza az átvételi elismervény. A holland bíróságok például a rendes peres eljárásban bírósági végrehajtó útján kézbesítik az iratokat, ez pedig a felperes feladata és felelőssége. Az ESC-eljárásról szóló törvény a kérelemmel induló eljárások (verzoekschriftprocedures) szabályait rendeli alkalmazni mögöttesen, ahol a bíróság felel a kézbesítésért, de ez még nem problémamentes a gyakorlatban. Egyes bíróságok meghosszabbították a határidőt a válaszadásra, míg más bíróságok ismételten kézbesítették az iratot. Egy bíróság azt jelezte a kérdőíven, hogy meghozza az ítéletet akkor is, ha nem érkezik vissza az átvételi elismervény, mivel vélelmezi, hogy a címzett megkapta az iratot. ${ }^{55}$ Ha még egy tagállamon belül sem egységes a gyakorlat, ez nyilvánvalóan a szabályozás pontosítását igényli, mivel jelenlegi formájában nem felel meg a jogbiztonság követelményének.

Több tagállamban problémaként jelentkezett, hogy a bíróság egyáltalán nem kézbesítette az ítéletet az alperes részére. Ez a rendelet szövegezése miatt lehetséges, mivel az a rendelkezés, hogy „az ítéletet kézbesíteni kell a feleknek”, nem elég részletes és konkrét követelmény arra vonatkozóan, hogy ezt a félnek kérelmeznie kell, és a bíróság feladata, vagy éppen a fél feladata, valamely más hatóság (pl. végrehajtó) útján. Emellett, ahol kézbesítették az ítéletet postai úton, azt a bíróság a saját nyelvén szövegezte meg, és nem mellékelt hozzá fordítást, így az alperes nem értette, ami alkalmat adott a megtagadásra. Ugyanakkor a megtagadás lehetőségéröl sem feltétlenül tájékoztatták az alperest, mivel az eddig nem volt része a bírósági értesítőnek. Ez az alperes eljárási jogosultságait sérti, mivel így nem szerez tudomást a megtagadáshoz való jogáról. ${ }^{56}$

\subsection{Az ítélet elleni fellebbezés lehetősége}

Az ítélet elleni fellebbezés megengedhetősége tekintetében a legtöbb tagállam a hazai általános szabályokra utal. Több tagállamban van fellebbezési értékhatár (pl. Bulgária, Csehország, Málta), vagy csak jogszabálysértésre lehet hivatkozni (pl. Ausztria). Van olyan tagállam, ahol az ESC-ítélet ellen kizárták a fellebbezést, miközben a hazai szabályok jóval megengedőbbek (Hollandia, Luxemburg). Úgy véljük, ez utóbbi megoldás nem mozdítja elő az ESC-eljárás igénybevételét, mert a fellebbezhetőség szempontjából érdemesebb a tagállami eljárást választani.

Figyelemre méltó, hogy Hollandiában az ESC-ítéletek ellen ki van zárva a fellebbezés, miközben egyéb ügyekben a fellebbezés általános értékhatára 1750 euró. ${ }^{57}$

54 Mellone, Marco: Legal Interoperability: the case of European Payment Order and of European Small Claims Procedure. In: Building Interoperability for European Civil Proceedings Online, IRSIG-CNR, 2013, 64.

55 Kramer Xandra E.-Ontanu, Alina: The functioning of the European Small Claims Procedure in the Netherlands: normative and empirical reflections. Nederlands Internationaal Privaatrecht, 2013/3, 319-328.

56 Kramer-Ontanu: i. m., 326.

57 Kramer-Ontanu: i. m., 326. 
A finn törvényben ${ }^{58}$ a fellebbezésröl a 4 . szakasz rendelkezik. Eszerint a Bírósági Eljárási Kódex szerint van helye az eljárásban hozott határozatok ellen fellebbezésnek, kivéve, ahol a rendelet azt kizárja. A svéd törvény ${ }^{59}$ szerint az ESC-ítéletek ellen fellebbezésnek van helye, amelyet a közlést követő 3 héten belül kell benyújtani a kerületi bírósághoz. Amennyiben az egyik fél fellebbezéssel élt az ítélettel szemben, az ellenfél még a másik fél fellebbezésének kézhezvételét követő egy héten belül fellebbezést nyújthat be. Ez hasonlóan a magyar csatlakozó fellebbezéshez, hatályát veszti, ha a fél fellebbezését visszavonja, vagy az bármely okból hatálytalanná válik. ${ }^{60}$

A francia CPC szerint az ESC-ítélet elleni jogorvoslat több típusú lehet, ám erre vonatkozóan csak a CPC általános, a tribunal d'instance bíróságok előtti eljárási szabályai adnak iránymutatást. ${ }^{61} \mathrm{~A}$ luxemburgi törvény ${ }^{62}$ szerint fellebbezésnek nincs helye az ESC-ítélettel szemben. Felülvizsgálati kérelemmel viszont lehet élni, a Semmítőszékhez.

A lengyel törvény szerint az ítélet elleni fellebbezésben két okra lehet hivatkozni, az anyagi jog megsértésére, annak téves vagy nem megfelelő alkalmazása miatt, és eljárási jogsértésre, ha az kihatott az ügy érdemére. ${ }^{63} \mathrm{Az}$ 505. 12. § szerint a fellebbezést a másodfokú bíróság elutasítja az anyagi vagy eljárási jogsértés ellenére is, ha az ítélet érdemben helyes. ${ }^{64}$

Az öZPO szerint az ESC-eljárásban hozott ítélet ellen van helye fellebbezésnek, de 2000 euró összeg alatt csak jogszabálysértésre hivatkozással, vagy az anyagi jogszabályok téves alkalmazása miatt. A fellebbezés határideje a közlést követő 4 hét. A fellebbezési eljárásban ügyvédi képviselet kötelezö. ${ }^{65}$ Bulgáriában a körzeti bíróságok ítélete ellen fellebbezésnek van helye a tartományi bíróságok előtt. A fellebbezést a határozatot hozó bíróságnál kell benyújtani, a kézhezvételtől számított 2 héten belül (a polgári eljárásjogi kódex 258. és 259. szakasza szerint). A magyar Pp. szerint szintén van helye fellebbezésnek az ítélettel szemben. ${ }^{66}$ Noha a rendelet 15. cikk (1) bekezdése kifejezetten rendelkezik arról, hogy az ítélet a lehetséges jogorvoslati eszközöktöl függetlenül végrehajtható, mivel a magyar jog szerint a fel-

58 753/2008. törvény, forrás: http://www.finlex.fi/en/laki/kaannokset/2008/en20080753 (2016. 06. 20.).

59 SFS 2008.1038. számú törvény. https://www.riksdagen.se/sv/dokument-lagar/dokument/svensk-forfattningssamling/lag-20081038-om-europeiskt-smamalsforfarande_sfs-2008-1038 (2016. 06. 20.).

60 Pp. 244. § (3) bekezdés.

61 Rendes jogorvoslat a CPC 571-578. szakaszai szerint. A rendkívüli jogorvoslat a Cour de Cassation előtti további fellebbezés (CPC 605-618-1. szakasza) és az ítélet felülvizsgálatának kérelmezése az ítéletet meghozó bíróság előtt (CPC 593-603. szakasza).

62 http://www.legilux.public.lu/leg/textescoordonnes/codes/nouveau_code_procedure_civile/PageAccueil.pdf (2016. 06. 20.).

63 Kodeks postępowania cywilnego, 505. 9. §, 505. 11. §, 505. 12. 1 és 3. bekezdés és 505. 13. §.

64 Ustawa z dnia 17 listopada 1964 r. Kodeks postępowania cywilnego. http://prawo.legeo.pl/prawo/ kodeks-postepowania-cywilnego-z-dnia-17-listopada-1964-r/czesc-pierwsza_ksiega-pierwsza_proces/ ?on=17.04.2016.

65 Information communicated by Member States in accordance with Article 25 of Regulation (EC) No 861/2007 of the European Parliament and the Council of 11 July 2007 establishing a European Small Claims Procedure. http://ec.europa.eu/justice_home/judicialatlascivil/html/pdf/vers_consolide_en_861.pdf (2016. 06. 20.), 34.

66 Pp. 233. §. 
lebbezés fő szabály szerint halasztó hatályú perorvoslat, az egyértelműség kedvéért célszerü a Pp.-ben rögzíteni azt, hogy az ESC-eljárásban a fellebbezésnek nincs halasztó hatálya. Ez azonban jelenleg csak a Vht. 13. § (3) szakaszából derül ki.

Egyes szerzők a rendelet hiányosságaként említik, hogy nem tartalmaz egységes szabályokat a fellebbezésre, hanem a tagállami jogra hagyja azt. ${ }^{67}$ Vélhetően a tagállami jogok másodfokú eljárásai közötti jelentős különbségek miatt nem történt ez meg, hiszen elöször az elsőfokú szabályozásban kívántak bizonyos fokú harmonizációt elérni, egy autonóm európai eljárás létrehozásával. A rendelet nem szól arról, hogy a másodfokon hozott ítélet is ESC-ítéletnek minősül-e, és a végrehajthatóságot ugyanúgy kell-e biztosítani, mint a rendelet alapján hozott elsőfokú ítélet esetében. A jogbiztonság, az ítéletek érvényesüléséhez füződő érdek ezt kívánná, miközben a tagállami jog alapján hozott ítéletet uniós rendelet alapján kell végrehajthatóvá nyilvánítani. Ezt az ellentmondást véleményünk szerint ki lehetne küszöbölni egy olyan rendelkezés beiktatásával, hogy a másodfokú ítéletek végrehajtása is a rendelet szerint történik.

\subsection{Az ítéletek kölcsönös elismerése és végrehajtása}

Az ESC-rendeletet megelőzően egy másik tagállamban hozott ítélet végrehajtására a 44/2001/EK rendelet ${ }^{68}$ végrehajthatóvá nyilvánításra vonatkozó szabályait kellett alkalmazni. Amennyiben az ügy nem tartozott a rendelet hatálya alá, akkor az elismerésre és a végrehajtásra irányadó nemzeti jogszabályokat, azaz hazánkban a nemzetközi magánjogról szóló 1979. évi 13. törvényerejü rendeletet (Nmjtvr.). Mindkét esetben széles körben lehetőség volt az elismerés megtagadására, és ezáltal a végrehajthatóvá nyilvánítás iránti kérelem elutasítására. ${ }^{69} \mathrm{~A}$ rendelet eltörli az exequatur eljárást, a tanúsítványt a származási állam bírósága állítja ki, a végrehajtást pedig nem előzi meg a végrehajthatóságra irányuló külön vizsgálat. Ugyanakkor az 1215/2012/EU rendelet ${ }^{70} a$ többi, határon átnyúló polgári és kereskedelmi ügyre is megszünteti a végrehajthatóvá nyilvánítási eljárást, és bevezet az ESC-rendelethez hasonló tanúsítványt, amelyet az eredetileg eljárt bíróság állít ki az 53. cikk alapján, és amely igazolja, hogy a határozat végrehajtható. ${ }^{71}$

Ezzel tehát megvalósult a határon átnyúló végrehajtás egyszerüsítése, de a szabályozás mégsem bizonyult teljesen sikeresnek. Mivel a tagállami végrehajtási szabályok nagyon különbözőek, és erröl, valamint hogy más tagállamban mely szerv rendeli el a végrehajtást, hová kell fordulni, nem áll rendelkezésre információ az Igazságügyi Atlaszban, ez pernyertesség esetén is további nehézségeket okozhat. Egy szélsőséges eset volt, amikor a tagállami bíró az ítélet végrehajtása érdekében

67 Kramer: i. m., 119-133.

68 A Tanács 44/2001/EK rendelete (2000. december 22.) a polgári és kereskedelmi ügyekben a joghatóságról, valamint a határozatok elismeréséről és végrehajtásáról.

69 Rendelet 34. cikk, Nmjtvr. 72. § (2) bekezdés.

70 Az Európai Parlament és a Tanács 1215/2012/EU rendelete (2012. december 12.) a polgári és kereskedelmi ügyekben a joghatóságról, valamint a határozatok elismeréséről és végrehajtásáról.

71 1215/2012/EU rendelet, 53. cikk. 
azt tanácsolta a jogosultnak, hogy forduljon az ECC-Net-hez a végrehajtás elrendelése érdekében (akinek egyáltalán nincs ilyen jogköre). ${ }^{72}$

Hollandiában ${ }^{73}$ a rendelet 21 . cikk (2) bekezdés b) pontja szerinti, a végrehajtáshoz csatolandó tanúsítvány holland nyelvü fordítása elfogadott. A finn törvény a végrehajtás megtagadásáról is rendelkezik, a 22. cikk (1) bekezdés esetében a Helsinki Körzeti Bíróság megtagadja a végrehajtást. A végrehajtás felfüggesztésére vagy korlátozására azonban nem a bíróság jogosult, hanem az eljáró végrehajtó, ő határoz a rendelet 23. cikke szerinti intézkedésekröl. A fordítások szükségessége kapcsán a finn törvény 7 . szakasza úgy rendelkezik, hogy amennyiben egy másik tagállamban hozott ESC-ítélet végrehajtását kérik a végrehajtótól, a kérelmezőnek a végrehajtó részére finn, svéd vagy angol nyelvü fordítást kell benyújtania a tanúsítványról. A végrehajtás kapcsán a svéd törvény ${ }^{74}$ csak a rendelet megfelelő cikkeire (15., 21., 22. és 23. cikk) hivatkozik, és semmilyen kiegészítő szabályt nem tartalmaz. Az ESC-eljárás keretében hozott ítéletet érintő tanúsítványok csak svéd vagy angol nyelven fogadhatók el. A végrehajtás tekintetében a Svéd Végrehajtási Hivatal (Kronofogdemyndigheten) rendelkezik hatáskörrel, és ő hozza meg a 23. cikk szerinti határozatokat is. ${ }^{75}$

A végrehajtáshoz szükséges formanyomtatvány nyelve tekintetében igen megengedő a francia szabályozás a többi tagállamhoz képest, ugyanis francia, angol, német, olasz és spanyol nyelven is elfogadja. A 23. cikk tekintetében, ha mulasztási ítélet született, és jogorvoslattal éltek az ítélettel szemben, az ítéletet hozó bíróság visszavonhatja az ítéletben elrendelt előzetes végrehajthatóságot, ami egyenértékü a végrehajtás felfüggesztésével. Emellett minden esetben elrendelheti a végrehajtás felfüggesztését a référé bíró sürgősségi okból, valamint a végrehajtásért felelős bíró a foganatosítás megkezdését követően, ha fizetési haladékot engedélyez az adósnak (CPC 510. szakasz). A bírósági hivatal (greffe) kérelemre kiállítja az ESCítéletre vonatkozó tanúsítványt. ${ }^{76}$

$A z$ angol törvény ${ }^{77}$ szintén szabályozza az ESC-ítéletek végrehajtását. A rendelet 21. cikkében megjelölt dokumentumokat kell benyújtani a végrehajtást elrendelö bírósághoz. Amennyiben egy külföldi pénznemben megadott értékü követelést kíván végrehajtani a jogosult, a kérelemnek kell egy tanúsítványt tartalmaznia az ítéletben szereplő követelésnek a kérelem dátumát megelőző nap üzleti záró időpontjában érvényes font egyenértékéröl [CPR 78.20. (2) bekezdés]. Ez a rendelethez képest

72 ECC-Net, European Small Claims Procedure Report, September 2012., 22. http://www.konsumenteuropa. se/globalassets/rapporter/european_small_claims_procedure_en.pdf (2016. 06. 20.).

73 Wet van 29 mei 2009 tot uitvoering van verordening (EG) nr. 861/2007 van het Europees Parlement en de Raad van de Europese Unie van 11 juli 2007 tot vaststelling van een Europese procedure voor geringe vorderingen, 7 . §.

74 Lag (2008:1038) om europeiskt småmålsförfarande, 7. §.

75 https://e-justice.europa.eu/content_small_claims-354-se-maximizeMS-en.do?member=1\#a_27 (2016. 06. 20.).

76 Commission européenne, Guide pratique pour l'application de la au titre du règlement (CE) $n^{\circ}$ 861/2007 du Parlement européen et du Conseil du 11 juillet 2007 instituant une procédure européenne de règlement des petits litiges. https://e-justice.europa.eu/fileDownload.do?id=6bb269cc-f23e-40ce-b8ea-4eff9babd5be (2016. 11. 20.).

77 https://www.justice.gov.uk/courts/procedure-rules/civil/rules/part78\#IDAPSOHC (2016. 06. 20.). 
többletelőírás nem könnyíti meg a végrehajtást kérő helyzetét, és indokolatlanul nehézzé teszi a végrehajtás kérelmezését más tagállamban hozott ESC-ítéletek esetében. A CPR 78.21. szakasza a végrehajtás megtagadásáról rendelkezik. A végrehajtás felfüggesztése vagy korlátozása iránti kérelem a rendelet 23. cikke szerint, szintén a CPR 23. Rész szabályai szerint terjeszthető elő, azon a bíróságon, ahol az ESC-ítélet végrehajtása folyamatban van. ${ }^{78}$

A lengyel polgári eljárásjogi kódex 795. 8. szakasza szerint az ítéletet meghozó bíróság állítja ki a rendelet szerinti tanúsítványt. A tanúsítványt bírósági titkár is kiállíthatja. A kiállítás tárgyában hozott határozat ellen fellebbezésnek van helye. A tanúsítvány elfogadott nyelve a lengyel, és csak hiteles fordítását fogadják el a szükséges dokumentumoknak. ${ }^{79}$ A 820. 2. § szerint a végrehajtható okirattal elrendelt végrehajtást az adós kérelmére felfüggesztheti a bíróság többek között akkor is, ha a rendelet szerinti feltételek fennállnak.

A ZPO 1105. § szerint a belföldön hozott ESC-ítéletek minden esetben előzetesen végrehajthatók. A perbíróság kérelemre dönthet a végrehajtás felfüggesztéséről vagy korlátozásáról, döntése nem fellebbezhető. A kérelmezőnek igazolnia kell a rendelet 23. cikke szerinti körülmények fennállását. A hazai ítéletek végrehajtási tanúsítvánnyal ellátásáról a 1106. $§$ rendelkezik. A tanúsítványt az a bíróság állítja ki, aki a végrehajtás elrendelésére jogosult. A tanúsítvány kiállítása előtt meg kell hallgatni az adóst. Ha a tanúsítvány iránti kérelmet elutasítja a bíróság, ugyanolyan jogorvoslat van ellene, mint a végrehajtás elrendelésének tárgyában hozott határozat ellen. Kiemeli, hogy nincs szükség végrehajthatóvá nyilvánításra, ha az ítéletet másik tagállamban hozták. A 1108. § szerint, a 21. cikk (2) bekezdés $b$ ) pont alapján kizárólag német nyelven kiállított, hiteles fordítás fogadható el. ${ }^{80}$

Ausztriában a végrehajtási tanúsítvány elfogadott nyelve a német. A végrehajtásra hatáskörrel rendelkező szervek a kerületi bíróságok, és ők döntenek a végrehajtás felfüggesztéséről vagy korlátozásáról a 23. cikk alapján. Luxemburgban a végrehajtási tanúsítvány nyelveként a francia és a német nyelv az elfogadott. A rendelet 23 . cikke alkalmazására a békebírók rendelkeznek hatáskörrel. ${ }^{81}$ Bulgáriában a végrehajtási tanúsítvány elfogadott nyelve a bolgár. $A$ végrehajtás elrendelése során azt kell vizsgálni, hogy a polgári eljárásjogi kódex 406. szakasza szerinti feltételek fennállnak-e. Erről végzést hoz a bíróság, ami fellebbezhető. ${ }^{82}$

A végrehajtás során a tanúsítvány fordítása szintén okozhat költségeket. A legtöbb bíróság a végrehajtás elrendeléséhez az ítélet és a tanúsítvány hiteles fordí-

78 Fauvarque-Cosson, Bénédicte-Behar-Touchais, Martine: Implementation of optional instruments within European civil law. European Parliament, Brussels, 2012, 107. http://www.europarl.europa.eu/RegData/etudes/etudes/join/2012/462425/IPOL-JURI_ET(2012)462425_EN.pdf (2016. 06. 20.).

79 The European Small Claims procedure in Poland, 14. http://www.europe-eje.eu/sites/default/files/pj/ dossiers/english_pol_petit_litigeenglish.pdf (2016. 06. 20.).

80 Fauvarque-Cosson-Behar-Touchais: i. m., 107.

81 The European Small Claims procedure in Luxembourg. http://www.europe-eje.eu/sites/default/files/pj/ dossiers/lux_petit_litigeenglish.pdf, 11. (2016. 11. 10.).

82 http://www.vks.bg/english/vksen_p04_02.htm (2016.06. 20.). 
tását kérte. ${ }^{83}$ Kevés tagállam fogadja el a sajátjától eltérő nyelveken kitöltött tanúsítványt. A rendelet felülvizsgálata során az egyik kritikus pont a fordítások magas költsége volt. Ezért törekedni kell arra, hogy az egyszerű fordítás elegendő legyen az eljárásban a végrehajtáshoz benyújtott okiratok tekintetében, ahogyan arra az Európai Fogyasztói Központ (ECC) holland tagszervezete is rámutatott jelentésében. ${ }^{84} \mathrm{~A}$ magas költségek és a végrehajtási problémák miatt a holland ECC többször azt tanácsolta a fogyasztóknak, hogy eleve a végrehajtás leendő helye szerinti tagállamban indítsák meg az eljárást. ${ }^{85}$

\section{Következtetések}

A tagállami szabályozások egyes pontjait elemezve arra juthatunk, hogy az adott tagállami eljárásjog ismerete nélkül valóban nem lehetséges az ESC-eljárásban való részvétel, mivel számos olyan részletszabály alkalmazása szükséges, amelyet csak a tagállami jog szabályoz, és önmagában a rendeletböl nem ismerhető meg. Bár az Igazságügyi Atlasz kiindulópontként hasznos lehet, de a megjelenített egységes információk bővítésre szorulnak. Mindenképpen tartalmaznia kellene a tagállami eljárási szabályokra való utalást, legalább a jogszabály megjelölésével. Még így sem valószínü, hogy jogi képviselő nélkül a felperes képes lenne az eljárást egy másik tagállamban végigvinni, különösen, ha a végrehajtásra is külföldön kerülne sor. Ez mindenképpen emeli az eljárási költségeket.

A tagállami szabályozást áttekintve a következő megállapításokat tehetjük. A rendelet által a tagállami jogokra hagyott, szabályozást igénylő kérdésekben voltak olyan közös pontok, melyek szinte valamennyi tagállamnál megtalálhatók voltak. Ezek általában azok a kérdéskörök, melyekre kiterjed a Bizottság felé fennálló tájékoztatási kötelezettség is. Ilyen a hatáskör és illetékesség, a részletes eljárási szabályok arra az esetre, ha a kereset vagy a viszontkereset a rendelet hatályán kívül esik, a fellebbezés megengedettsége, a végrehajtási tanúsítványt kiállító szerv és a végrehajtáshoz elfogadott nyelvek, és a végrehajtás felfüggesztésére és korlátozására jogosult szerv.

Emellett voltak az adott tagállamra jellemző, speciális elöírások is. Ezek egyik részét az általános szabályoktól való eltérések indokolták vagy a rendelet nem kellően részletes szabályozása. Ilyen például a német szabályozásban a tárgyalás távoli eszköz útján, a bizonyítás módja, az ítélet közlésének módja, a lengyel szabályozásban a keresetlevél visszaküldése végzéssel, a tárgyaláson kívüli elbírálás és az írásbeli tanúvallomás. Vagy ilyennek tekinthető az osztrák szabály, amely kizárja az ítélkezési szünet alkalmazását az ESC-eljárásban. Három tagállam szabályozása tartalmazza a mulasztási ítélet meghozatalának lehetőségét, a rendelet 7 . cikk

${ }^{83}$ ECC-Net, European Small Claims Procedure Report, September 2012, 28. http:/lec.europa.eu/consumers/ ecc/docs/small_claims_210992012_en.pdf (2016. 06. 20.).

${ }^{84}$ ECC-Net, European Small Claims Procedure Report, September 2012., 25. http://www.konsumenteuropa. se/globalassets/rapporter/european_small_claims_procedure_en.pdf (2016. 06. 20.).

85 ECC-Net, European Small Claims Procedure Report, September 2012., 30. http://www.konsumenteuropa. se/globalassets/rapporter/european_small_claims_procedure_en.pdf (2016. 06. 20.). 
(3) bekezdése esetére, és az ehhez füzödő jogkövetkezményeket (Németország, Ausztria, Svédország). Ezek a kiegészítő szabályok szükségesek a rendelet gyakorlati alkalmazásához. Az uniós jogalkotónak érdemes lenne az említett kérdésköröket beépíteni a rendeletbe, hiszen az feleslegessé tenné a külön szabályozást.

Találtunk azonban egyes szabályokat, melyek olyan többletkövetelményeket határoznak meg a felek számára, amelyek a rendeletböl nem következnek, és esetenként a tagállami joghoz képest is szigorúbb vagy hátrányosabb elöírásokat jelentenek, vagy kifejezetten megnehezítik az ESC-eljárás alkalmazását. Ilyen a Luxemburgban alkalmazott kettős kézbesítési rendszer, amely kiszámíthatatlanná teszi a kézbesítést, a másik az angol szabályozás, amely többletkövetelményt tartalmaz a keresetlevére (valódisági nyilatkozat) és a végrehajtás iránti kérelemre is. Ezen utóbbi előírások véleményünk szerint kifejezetten ellentétesek a rendelet céljával, nem feltétlenül szükségesek a rendelet alkalmazásához, sőt a hatékony érvényesülés akadályát is jelenthetik.

A hatékony jogalkalmazás feltétele, hogy minél kevesebb ilyen speciális rendelkezés legyen, ezáltal biztosítva, hogy minden tagállamban egyformán folytatják le az ESC-eljárást. Azonban azt is leszögezhetjük, hogy ez csak akkor lehetséges, ha a rendelet kimerítően szabályozza az eljárás minden egyes pontját, ezáltal a rendelet közvetlen alkalmazása révén megakadályozza, hogy a tagállamok eltérjenek az eljárás egyes részletszabályaiban. Nem kívánt azonban az uniós jogalkotó ilyen, felülről a tagállamokra kényszerített szabályozással élni, hanem a tagállamok saját eljárásjogi környezetében próbálta megvalósítani az ESC-eljárást, remélve, hogy egy közös európai eljárás indirekt módon közelebb hozza a tagállami polgári eljárásjogi szabályokat. Ez azonban nem látszik megvalósíthatónak, inkább a tagállamok közös nevezőjeként létrehozott részletes szabályozás lenne a kedvezöbb út, de ennek megteremtése bizonyosan nem lesz sem egyszerü, sem gyors. A piaci igények sürgetik a helyzet megoldását, és így más, nem bírói úton történő vitarendezési módok átmenetileg elötérbe kerülhetnek, mivel azokat nem egy létező struktúrába (mint a hagyományos polgári peres eljárás) próbálják beleszorítani, hanem eleve új vitarendezési mechanizmusokat hoznak létre. Véleményünk szerint azonban hoszszú távon az igazságszolgáltatás visszanyeri elsődleges szerepét, amennyiben képes lesz arra a megújulásra, amire az olyan eszközök inspirálhatják a tagállamokat, mint például az ESC-eljárás.

Számos problematikus pont is felmerült a rendelet alkalmazása során, amire meglehetősen nehéz lesz a jogalkotónak választ adnia. Ezek körében a rendelet 2015-ben elfogadott módosítása ${ }^{86}$ nyomán néhány elöremutató változás történt, például az alperes védelmének fokozása érdekében a formanyomtatványoknak tájékoztatást kell tartalmazniuk arról, hogy milyen következményekkel jár, ha nem vitatja a követelést, vagy nem jelenik meg a tárgyaláson, különös tekintettel annak lehetőségére, hogy ítéletet hozhatnak vagy hajthatnak végre vele szemben, és kötelezhetik őt az eljárás költségeinek viselésére. Arról is tájékoztatást kell nyújtani, hogy

86 Az Európai Parlament és a Tanács (EU) 2015/2421 rendelete (2015. december 16.) a kis értékű követelések európai eljárásának bevezetéséről szóló 861/2007/EK rendelet, valamint az európai fizetési meghagyásos eljárás létrehozásáról szóló 1896/2006/EK rendelet módosításáról. 
a pernyertes fél számára nem térítik meg az eljárás költségeit, amennyiben azok indokolatlanul merültek fel, vagy a követelés értékéhez képest aránytalanok voltak.

A problémák egy része az eljárás azon természetéből fakad, hogy annak egyes aspektusait a tagállami eljárásjog szabályozza és e téren - a módosítást követően - sincs kilátásban egységes szabályozás. További gondot jelent, hogy az eljárás gördülékeny müködése a tagállamok és ezen belül nemcsak a bíróságok, de a végrehajtók között is új együttmüködési mechanizmusok kialakítását teszi szükségessé. Ennek mikéntjét a rendelet nem dolgozta ki kellő részletességgel, vélhetően ez az oka, hogy a gyakorlatban mindeddig nem valósult meg.

Az eljárás igazi előnye a felek személyes jelenléte nélkül megvalósítható ügymenet, és az elektronikus kommunikációs eszközök kihasználása. A technika azonban ez idáig nem érte utol a rendelet elöremutató szabályait, de ez reményeink szerint a következő néhány évben megváltozik. Azt is figyelembe kell azonban venni, hogy ha egy uniós rendelet a már meglévő, jól ismert eljárások mellé ad egy alternatív eszközt a jogkeresők kezébe, még hosszú ideig a bevált, a gyakorlatban használt hazai eljárást fogják preferálni, akkor is, ha egyébként hosszú távon az új eljárás hatékonyabb lenne. Az új eljárás előnyei csak akkor fognak jelentkezni, ha a jogalkalmazók megteremtik annak sajátos, a tagállami eljárástól eltérő gyakorlatát.

\footnotetext{
Abstract

It has been seven years since the European Small Claims Procedure was introduced as a sui generis European procedure and an alternative to existing national civil procedures. However, it works in close interaction with national laws, as the regulation leaves many aspects of the procedure to national legislation. The article analyzes the legal instruments that serve the implementation of regulation 861/2007/ EC in member states, particularly the issues of mutual recognition and enforcement of ESC judgments, communication between the court and the parties, review and appeal of the judgment, and other specific issues. It concludes that knowledge of national procedural law is often vital to succeed in an ESC procedure in a foreign country. Smooth and efficient functioning of the procedure requires cooperation mechanisms not only among member states, but also among judges, lawyers, and enforcement officers.
} 